Pesq. Vet. Bras. 36(3):141-144, março 2016 DOI: $10.1590 /$ S0100-736X2016000300001

\title{
Testing pigs of non-technified rearing farms for serum antibodies against Taenia solium in a region of the state of São Paulo, Brazil ${ }^{1}$
}

\author{
Gabriel A.M. Rossi ${ }^{2 *}$, Henrique M.S. Almeida², Rafaella P.M. Guimarães-Peixoto ${ }^{3}$, Emílio C. \\ Acevedo-Nieto ${ }^{3}$, Paulo S.A. Pinto ${ }^{3}$, Ana Maria C. Vidal ${ }^{4}$, Luis A. Mathias ${ }^{2}$ and Luis G. Oliveira ${ }^{5}$
}

\begin{abstract}
Rossi G.A.M., Almeida H.M.S., Guimarães-Peixoto R.P.M., Acevedo-Nieto E.C., Pinto P.S.A., Vidal A.M.C., Mathias L.A. \& Oliveira L.G. 2016. Testing pigs of non-technified rearing farms for serum antibodies against Taenia solium in a region of the state of São Paulo, Brazil. Pesquisa Veterinária Brasileira 36(3):141-144. Departamento de Medicina Veterinária Preventiva e Reprodução Animal, Faculdade de Ciências Agrárias e Veterinárias, Universidade Estadual Paulista, Via de acesso Paulo Castellane s/n, Jaboticabal, SP 14884-900, Brazil. E-mail: gabrielrossiveterinario@gmail.com

Taenia solium is a zoonotic tapeworm of great importance in developing countries, due to the occurrence of human taeniasis and cysticercosis. Pigs have an important role in the biological cycle of the parasite as intermediate hosts. The scientific literature has been describing risk factors associated with the occurrence of this disease that must be avoided in countries with poor sanitation, in order to reduce the exposure of swine to the parasite eggs. This research focused on testing pigs of non-technified rearing farms for serum antibodies against Taenia solium in the region of Jaboticabal municipality, in the state of São Paulo, Brazil. The found prevalence was 6.82\% (CI 95\% 4.18 - 9.45) at animal level and 28.87\% (CI $95 \% 16.74-40.40$ ) at herd level. These figures are probably associated with low technification adoption during animal rearing in the studied area, which increased the exposure of the animals to risk factors associated with the occurrence of Taenia solium complex. The results found based on serological evidences of swine cysticercosis in the studied region serves as a warning to public sanitary authorities to improve public health and control T. solium.
\end{abstract}

INDEX TERMS: Taenia solium, cysticercosis, epidemiology, public health, tapeworm, zoonosis.

RESUMO.- [Anticorpos séricos contra Taenia solium em suínos de criações não tecnificadas em uma região do Estado de São Paulo, Brasil.] A Taenia solium é uma importante zoonose com grande importância em países em

\footnotetext{
${ }^{1}$ Received on October 20, 2015.

Accepted for publication on December 26, 2015.

${ }^{2}$ Departamento de Medicina Veterinária Preventiva e Reprodução Animal, Faculdade de Ciências Agrárias e Veterinárias (FCAV), Universidade Estadual Paulista (Unesp), Via de acesso Paulo Castellane s/n, Jaboticabal, SP 14884-900, Brazil. *Corresponding author: gabrielrossiveterinario@ gmail.com, henri_almeida2003@yahoo.com.br, lmathias@fcav.unesp.br

${ }^{3}$ Departamento de Veterinária, Universidade Federal de Viçosa (UFV), Avenida Peter Henry Rolfs s/n, Viçosa, MG 36570-900, Brazil. E-mail: rafinhapaola@hotmail.com, ecanieto@yahoo.com.br, pintopsa@ufv.br

${ }^{4}$ Departamento de Medicina Veterinária, Faculdade de Zootecnia e Engenharia de Alimentos (FZEA), Universidade de São Paulo (USP), Avenida Duque de Caxias Norte 225, Pirassununga, SP 13635-900, Brazil. E-mail: anavidal@usp.br

${ }^{5}$ Departamento de Clínica e Cirurgia Veterinária, FCAV-Unesp, Via de acesso Paulo Castellane s/n, Jaboticabal, SP 14884-900, Brazil. E-mail: luis.guilherme@fcav.unesp.br
}

desenvolvimento, devido a ocorrência de teníase e cisticercose em humanos. Os suínos possuem grande importância no ciclo biológico desse parasita como hospedeiros intermediários. A literatura científica descreve alguns fatores de risco associados com a ocorrência da enfermidade e que devem ser evitados em países com baixo saneamento básico a fim de reduzir a exposição dos suínos aos ovos do parasita. Assim, objetivou-se avaliar a presença de anticorpos séricos contra Taenia solium em suínos de criações não tecnificadas na região do Município de Jaboticabal, Estado de São Paulo, Brasil. A prevalência estabelecida foi de $6,82 \%$ (IC $95 \%$ 4,18 - 9,45) a nível animal e 28,87\% (IC 16,74 - 40,40) nos rebanhos. Isso está provavelmente associado ao baixo nível de tecnificação adotado durante a criação dos animais na área avaliada, o qual aumenta a exposição dos animais aos fatores de risco associados ao complexo Taenia solium. Os resultados da ocorrência de cisticercose suína baseados em evidências sorológicas na região avaliada servem como um alerta as autoridades sanitárias para promover a saúde pública e controlar a Taenia solium. 
TERMOS DE INDEXAÇÃO: Taenia solium, cisticercose, epidemiologia, saúde pública, tênia, zoonoses.

\section{INTRODUCTION}

Taenia solium is a tapeworm that causes two important foodborne diseases common in developing countries with poor sanitation: taeniasis and cysticercosis. Pigs are the intermediate hosts of the parasite, while humans are both definitive hosts (taeniasis) and intermediate hosts (cysticercosis) (OIE 2014). The ingestion of water or food contaminated with the parasite's eggs are the main infection pathway of human cysticercosis. In the event of eggs ingestion, neurocysticercosis commonly occurs and is considered one of the most important diseases in Latin America (Flisser et al. 2003) and the major cause of epileptic seizures in Brazil (Ishida et al. 2006).

Human cysticercosis is widely distributed in Brazil (Silveira-Lacerda 2002, Prestes-Carneiro et al. 2006, Sato et al. 2006, Ishida et al. 2011, Silva et al. 2007) and its occurrence is usually associated with the exposure to risk factors such as: pig rearing together with kitchen gardening (Ishida et al. 2011), consumption of under-cooked pork (Prasad et al. 2007), human defecation in inappropriate areas and the lack of hand washing after defecating (Weka et al. 2013). Moreover, Pinto et al. (2002) compared the cysticercosis occurrence in swine slaughtered with and without sanitary inspection. The authors proved that the consumption of pork slaughtered without sanitary inspection presented a great public health risk. This practice is common in Brazil and other developing countries.

Pigs get infected with the cysticerci by ingesting food or water contaminated with T. solium eggs, parasite segments, human feces containing eggs (OIE 2014) or even direct pig-to-pig transmission (Gonzalez et al. 2006). The main risks factors associated with swine cysticercosis are free-range husbandry system, absence of bathrooms in the rearing farms, contaminated water ingestion (Sikasunge et al. 2007, Morales et al. 2008) and slaughter without sanitary inspection (Pinto 2000).

The occurrence of this disease varies among studies performed in Brazil (Sakai et al. 2001, Falavigna-Guilherme et al. 2006, Silva et al. 2007, Acevedo-Nieto 2011, Acevedo-Nieto et al. 2012, Aragão et al. 2012, Felippe et al. 2014). The prevalence in pigs reared in technified farms in the state of São Paulo, Brazil, was very low $(<0.1 \%$ ) (Almeida et al. 2014), on the other hand, few studies evaluate the prevalence of swine cysticercosis in animals of non-technified farms. The only other one, also performed in the state of São Paulo, evaluated pigs from non-technified farms at Registro municipality using ELISA and found 20.5\% (113/551) of positive animals (Gottschalk et al. 2006).

This research focused on testing pigs of non-technified rearing farms for serum antibodies against T. solium in the region of Jaboticabal municipality, in the state of São Paulo, Brazil.

\section{MATERIAL AND METHODS}

Area characterization and sample collection. The study was performed according to ethical standards and procedures for animal's researches with protocol number 07998/14 (Ethical Comission in Animal Use - Jaboticabal.) Blood samples of 352 pigs reared in 56 different non-technified farms in the region of Jaboticabal municipality, state of São Paulo, Brazil, were collected during the years 2014 and 2015. The farms included in this study were located in 12 different municipalities: Borborema (2), Guariba (1), Guatapará (2), Ibitinga (1), Itápolis (3), Jaboticabal (18), Monte Alto (4), Motuca (11), Pradópolis (4), Taiaçu (5), Taíuva (1) and Taquaritinga (4).

The age of the sampled animals ranged from three months up to two years old. The blood was collected through jugular punction and transported refrigerated to the laboratory. The serums were obtained after centrifugation of the total blood and afterwards were stored in a freezer at $-20^{\circ} \mathrm{C}$.

The farm selection was not probabilistic because the inclusion in the study was voluntary. The only criteria adopted for the inclusion was the low level of technification. The farms included in this study didn't adopt biosecurity practices according to veterinary recommendation, used free-range system in animal rearing, and did not have sanitary control of the water or food offered. In herds with five animals or less, all of them were sampled, but in larger herds, $10 \%$ of the animals were randomly chosen for sample collection.

In order to determinate the sample size required to perform this study the following equation was used:

$$
\mathrm{n}=\frac{\mathrm{z}^{2} \cdot \mathrm{p} \cdot \mathrm{q}}{\mathrm{d}^{2}}
$$

$\mathrm{n}$ = sample size, $\mathrm{Z}=$ standard deviation, $\mathrm{p}=$ expected prevalence, $\mathrm{q}=1-\mathrm{p}$, and $\mathrm{d}=$ maximum admitted error, according to Thrusfield (2010).

The pig population in this region was 4,100 animals (São Paulo 2008 ), the expected disease's prevalence of $1 \%$, since there are no other studies with non-technified farms animals in this region, and a maximum admitted error value of $2.5 \%$. The obtained value (n) was corrected (nc) to the population size using the equation:

$$
\mathrm{nc}=\frac{\mathrm{n} x N}{\mathrm{n}+N}
$$

As a result, to accomplish this study's objective, at least 246 blood samples were necessary.

Laboratory analysis. The sample screening was performed using an indirect ELISA test and the positive samples were subjected to a Western Blot assay to confirm the diagnosis. The prevalence was estimated using the Western Blot assay results. The serological tests used a heterologous total antigen of Taenia crassiceps according to the following methodology established by Pinto et al. (2000) and Pinto et al. (2001). The sensitivity and specificity of the performed ELISA test is respectively, $100 \%$ and $98 \%$. For the Western Blot the values are $76.9 \%$ of sensitivity and $98.5 \%$ of specificity.

ELISA. Polystyrene sensitized plates were used with antigen diluted in carbonate-bicarbonate buffer $0.5 \mathrm{M} \mathrm{pH} 9.6$ for 12 hours at $4^{\circ} \mathrm{C}$, preceded by incubation at room temperature for one hour. After washing in saline solution containing $0.05 \%$ Tween-20, the reactive sites were blocked with 5\% skimmed milk in PBS pH 7.4 for 1 hour at $37^{\circ} \mathrm{C}$. New washes were performed and serum samples were diluted at 1:12.5 for pigs in 1\% skimmed milk in PBS pH 7.4, and the plate was incubated for 30 minutes at $37^{\circ} \mathrm{C}$. After washing, the conjugate (peroxidase-labeled rabbit anti-pig IgG, A5670, Sigma Chemical Co., St Louis, MO, USA) was diluted at 1:5000 and added, and the procedures of incubation and washing were repeated. The reaction was developed with 0.1\%o-phenylenediaminedihydrochloride - OPD, 
P8287 (Sigma Chemical Co., St Louis, MO, USA) and 0.003\% $\mathrm{H}_{2} \mathrm{O}_{2}$ in $0.2 \mathrm{M}$ citrate phosphate buffer ( $\mathrm{pH}$ 5.0) during an incubation period of 5 minutes. The reaction was blocked with $4 \mathrm{~N} \mathrm{H}_{2} \mathrm{SO}_{4}$ and readings were conducted in a spectrophotometer at $492 \mathrm{~nm}$. The amount of reagents applied to each well of the plate was $100 \mu$, except for blocking, which was performed with $200 \mu \mathrm{l}$. In order to minimize the differences between the plates, facilitate comparison and provide a more accurate result, the cut-off point was calculated from the mean values of optical densities (OD) of negative controls on each plate plus two standard deviations (2SD). The OD readings were adjusted for each plate by the correction factor, which was calculated from the difference between the mean of the negative and the positive controls of the standard plate, divided by the difference between the mean of the negative and the positive controls of the test plate.

Western Blot. After electrophoresis, the important peptides for the diagnosis $(4-6,14$ and $18 \mathrm{KDa}$ ) were separated by SDSPAGE and transferred from gel to nitrocellulose membranes 0.2 (Millipore, USA) according to the method described by Towbin et al. (1979), using a transfer buffer solution containing methanol (25mM Tris-hidroximetilaminoetano; $192 \mathrm{~mm}$ glycine and $20 \%$ methanol -v/v-, pH 8.3). The transfer was performed for a period of 1 hour at room temperature with current of $50 \mathrm{~mA}$ and constant voltage of 17V (Bio-Rad Laboratories, Hercules, CA, USA). After transfer, the nitrocellulose membranes were stained with Ponceau-S 0.5\% aqueous solution, for qualitative and quantitative viewing of the transfer. Strips of 3 to $4 \mathrm{~mm}$ in width were obtained from the membranes, and they were bleached and washed three times in saline $(0.15 \mathrm{M} \mathrm{NaCl})$ containing $0.05 \%(\mathrm{v} / \mathrm{v})$ Tween-20. The strips were treated with blocking solution of $5 \%$ skim milk dissolved in Tris-saline $(10 \mathrm{mM}$ Tris-hydroxymethylaminomethane) and $0.15 \mathrm{M} \mathrm{NaCl}, \mathrm{pH} 7.4$, by heating to about $90{ }^{\circ} \mathrm{C}$ and filtering through filter paper for an hour under slow stirring at room temperature. Diluting solution was added to the serum samples. Serum samples analyzed in a diluting solution (blocking solution diluted $1 / 5$ in Tris-saline) were diluted at 1:100 and added to the strips, and incubation was performed for $14-18$ hours at $4^{\circ} \mathrm{C}$ under slow stirring. After six 5-min washes, the strips were incubated again for one hour with the conjugate (peroxidase-labeled rabbit anti-pig(A-5670), Sigma Chemical Co., St. Louis, MO, USA), suitably diluted at 1:1000, and then new washes were performed. The peptides were evidenced as reactive with the chromogen solution (5mg diaminobenzidine, $1.5 \% \mathrm{H}_{2} \mathrm{O}_{2}$ in $\mathrm{PBS} \mathrm{pH}$ 7.2) for about 10 minutes. Then, the strips were rinsed with distilled water and dried. Sero-positivity or sero-negativity was based on the presence or absence of reaction with the aforementioned peptides. The molecular weight markers used ranged from about $205 \mathrm{kD}$ to $6.5 \mathrm{kD}$ (Sigma M-4038).For the test, the total antigen of Taenia crassiceps was used at a concentration of 6ìg/ml (Pinto et al., 2001).

Statistical analysis. A 95\% confidence interval (CI 95\%) was estimated to all prevalence values obtained according to the methodology proposed by Thrusfield (2010).

\section{RESULTS AND DISCUSSION}

In total, 352 swine blood samples from 56 different farms were collected. For epidemiological purposes, each farm was considered as one single herd in this study. Table 1 shows the prevalence results at animal level and at herd level.

The prevalence of cysticercosis at animal level was 6.82\% (C.I 95\% 4.18-9.45) and 28.87\% (C.I 95\% 16.7440.40) at herd level. The low level of technification adopted in those farms during the animal rearing matches the prevalence values found. Thus, there is no sanitary inspection during this animal's slaughter, increasing the risk of Tae-
Table 1. Prevalence and CI $95 \%$ of swine cysticercosis in the region of Jaboticabal municipality, São Paulo State, Brazil, using indirect ELISA test as screening and Western Blot as confirmatory for cysticercosis diagnostic.

\begin{tabular}{lcccc}
\hline & Positives & Negatives & Total & Prevalence ( 95 \% C.I) \\
\hline Animals & 24 & 328 & 352 & $6.82(4.18-9.45)$ \\
Farms & 16 & 40 & 56 & $28.57(16.74-40.40)$
\end{tabular}

nia solium occurrence in the population and, consequently, causing public health issues in Brazil (Pinto 2002).

The farms included in this study used free-range system in animal rearing, and did not have sanitary control of the water offered; sometimes the animals had free access to rivers usually contaminated with sewage from nearby cities and other farms. The scientific literature points out free-range husbandry systems, absence of toilet in the farm, access to contaminated water and the animal slaughter without sanitary inspection as the main risk factors related to swine cyticercosis (Pinto 2000, Sikasunge et al. 2007, Morales et al. 2008). The presence of these factors in the farms of this study could justify the high prevalence (28.87\%) at farm level.

The high population density (166.23 humans $/ \mathrm{km}^{2}$ ) in the state of São Paulo (IBGE 2014) could also explain the high prevalence of swine cysticercosis. High-populated areas are prone to have more infected humans and consequently more eggs spreading in the environment where the animals are and contaminating the food/water, offered without sanitary control.

The prevalence value found agrees with Silva et al. (2007) that detected cysticercosis in 4.7\% (4/85) of the pig carcasses at meat sanitary inspection in the state of Ceará. Sakai et al. (2001) detected 12.08\% (29/240) cysticercis infected pigs in the state of Bahia. Acevedo-Nieto (2011) found $5.26 \%$ (13/247) of infected pigs in Tumiritinga municipality, state of Minas Gerais.

Gottschalk et al. (2006) evaluated pigs from non-technified farms in the Registro region, state of São Paulo, and established that $20.5 \%$ (113/551) of the animals were cysticercosis positive. All the authors cited above found higher prevalence values when compared to this research because they used only the ELISA as diagnostic test without Western Blot to confirm the positives. On the other hand, the disease was not reported in animals slaughtered in the state of $\mathrm{Pa}$ raná (Falavigna-Guilherme et al. 2006) and in rural areas of Matias Barbosa and Divinésia municipalities, in the state of Minas Gerais (Acevedo-Nieto et al. 2012, Felippe et al. 2014).

The cysticercosis prevalence in carcasses of pigs reared in technified farms and slaughtered in the state of São Paulo was less than $0.1 \%$ (Almeida et al. 2014), proving that the correct adoption of biosecurity measures during animal rearing enables to, control the diseases' associated risk factors, reducing its prevalence.

Some farmers claimed to slaughter the animals without sanitary inspection for self-consumption, a habit that contributes to raise the occurrence of T. solium in humans and, consequently, the cysticercosis in animals of the same farm. Pinto et al. (2002) found higher values of cysticercosis in pigs slaughtered without sanitary inspection, which allied with consumption of undercooked pork meat poses high risks to public health. 
Prestes-Carneiro et al. (2006) evaluated cysticercosis occurrence in peasant's settlement inhabitants in the state of São Paulo and found 3.6\% of infected humans. In addition, neurocysticercosis is the major cause of epileptic seizure in Brazil (Ishida et al. 2006). This study evaluated animal samples from peasant's settlements, reinforcing the appeal for health authorities to improve basic sanitation at rural communities, aiming on reducing treatment costs and promoting public health in these populations.

The main prophylactic actions in endemic areas are based on local population health education, to prevent the consumption of undercooked pork and uninspected meat (OIE 2014); mass treatment of human population; prevent pigs access to human feces or contaminated water and food; cestodicidal treatment of infected animals and improving regional basic sanitation (Flisser et al. 2003).

\section{CONCLUSION}

The prevalence of cysticercosis in pigs reared in non-technified farms in Jaboticabal region, state of São Paulo, Brazil, was 6.82\% (C.I 95\% 4.18-9.45) at animal level and $28.87 \%$ (C.I 95\% 16.74-40.40) at herd level. Our results, based on serological evidences of cysticercosis occurrence, serves as a warning to sanitary authorities to control Taenia solium and improve the regional population health status.

\section{REFERENCES}

Acevedo-Nieto E.C. 2011. Epidemiologic profile of taeaniasis-cysticercosis complex in rural area of Tumiritinga, MG. Master Dissertation, Universidade Federal de Viçosa, Viçosa, MG. 64p. Disponible in <http://www.tede.ufv. br/tedesimplificado/tde_arquivos/8/TDE-2011-10-21T112057Z-3165/ Publico/texto\%20completo.pdf> Accessed on August 18, 2015.

Acevedo-Nieto E.C., Ferreira P.S., Santos T.O., Peixoto R.P.M.G., Silva L.F., Fellipe A.G., Pinto P.S.A. \& Caldi J.F.B. 2012. Prevalence of teniasis-cysticercosis complex in a rural area of Matias Barbosa, MG. Semin: Ciênc. Agrárias 33:2307-2314.

Almeida H.M.S., Rossi G.A.M., Gatto I.R.H., Gonçalves A.C.S., Ribeiro L.F., Garnica M.F., Oliveira M.E.F., Vidal-Martins A.M.C. \& Oliveira L.G. 2014. Occurrence of cysticercosis in pigs at slaughterhouses in São Paulo State, Brazil. Proceedings of the 23rd International Pig Veterinary Society (IPVS) Congress, Cancun, Quintana Roo, Mexico. 2 volumes, p.407. Disponible in <http://www.ipvs2014.org/_content/pdf/ProceedingsIPVS2014Volume-2.pdf> Accessed on August 4, 2015.

Aragão S.C., Biondi G.F., Lima L.G.F. \& Nunes C.M. 2010. Animal cysticercosis in indigenous Brazilian villages. Braz. J. Vet. Parasitol. 19:132-134.

Falavigna-Guilherme A.L., Silva K., Araújo S.M., Tobias M.L. \& Falavigna D.L.M. 2006. Cysticercosis in animals of Sabáudia, Paraná State. Arq. Bras. Med. Vet. Zootec. 58:950-951.

Felippe A.G., Pinto P.S.A., Santos T.O., Acevedo-Nieto E.C. A., Peixoto R.P.M.G. \& Silva L.F. 2014. Favorable characteristic for control of taeniosis-cysticercosis complex in a rural region of Minas Gerais, Brazil. Revta Bras. Ciênc. Vet. 21:243-246.

Flisser A., Sarti E., Lightowlers M. \& Schantz P. 2003. Neurocysticercosis: regional status, epidemiology, impact and control measures in the Americas. Acta Trop. 87:43-51.

Gonzalez A.E., Lopez-Urbina T., Tsang B., Gavidia C., Garcia H.H., Silva M.E., Ramos D.D., Manzanedo R., Sanchez-Hidalgo L., Gilman R. \& Tsang V.C. 2006. Cysticercosis working group in Peru: transmission dynamics of Taenia solium and potential for pig-to-pig transmission. Parasitol. Int. 44:S131-135.

Gottschalk S., Buzi K.A., Galindo L.A., Abreu B.X., Nunes C.M. \& Biondi G.F. 2006. Seroprevalence and epidemiological aspects of cysticercosis of swine "raised in backyard" in the Registro microregion, São Paulo State. Vet. Zootec.13:192-200.
IBGE 2014. Brazilian Institute of Geography and Statistics. São Paulo State. Disponible in <http://www.ibge.gov.br/estadosat/perfil.php?sigla=sp> Accessed on August 15, 2015.

Ishida M.M.I., Peralta R.H.S., Livramento J.A., Hoshino-Shimizu S., Peralta J.M. \& Vaz A.J. 2006. Serodiagnosis of neurocysticercosis in patients with epileptic seizure using ELISA and Immunoblot assay. Revta Instit. Med. Trop. São Paulo 48:343-346.

Ishida M.M.I., Almeida M.S.S., Espíndola N.M., Iha A., Pereira D.A., Souza J.G., Varvakis T.R. \& Vaz A.J. 2011. Seroepidemiological study of human cysticercosis with blood samples collected on filter paper, in Lages, State of Santa Catarina, Brazil, 2004-2005. Revta Soc. Bras. Med. Trop. 44:339-343.

Morales J., Martínez J.J., Rosetti M., Fleury A., Maza V., Hernandez M., Villalobos N., Fragoso G., Aluja A.S., Larralde C. \& Sciutto E. 2008. Spatial distribution of Taenia solium porcine cysticercosis within a rural area of Mexico. PloSNegl. Trop. Dis. 2:e284.

OIE 2014. Terrestrial Manual, World Organization for Animal Health. Cap. 2.9.5, p.1-12. Disponible in <http://www.oie.int/fileadmin/Home/eng/ Health_standards/tahm/2.09.05_CYSTICERCOSIS.pdf> Acessed on August 11, 2015.

Pinto P.S.A., Vaz A.J., Germano P.M.L. \& Nakamura P.M. 2000. Performance of the ELISA test for swine cysticercosis using antigens of Taenia solium and Taenia crassiceps cysticerci. Vet. Parasitol. 88:127-130.

Pinto P.S.A., Vaz A.J., Nakamura P.M. \& Germano P.M.L. 2001. Immunoblot analysis using antigen from Taenia crassiceps cysticerci in the diagnosis of swine cysticercosis. Boln Chil. Parasitol. 56:36-42.

Pinto P.S.A., Almeida L.P., Germano P.M.L., Vaz A.J. \& Nakamura P.M. 2002. Cysticercosis occurrence and sanitary risks in group of inspected and non-inspected swine in Brazil. Parasitol. Latinoam. 57:129-133.

Prasad K.N., Prasad A., Gupta R.K., Pandey C.M. \& Singh U. 2007. Prevalence and associated risk factors of Taenia solium taeniasis in rural pig farming community of north India. Trans. R. Soc. Trop. Med. Hyg. 101:1241-1247.

Prestes-Carneiro L.E., Freitas S.B.Z., Zago S.C.S., Miguel N.A., Primo O.B., Iha A.H., Espíndola N.M. \& Vaz A.J. 2006. Taeniosis-cysticercosis complex in individuals of a peasant's settlement (Teodoro Sampaio, Pontal of Parapanema, SP, Brazil). Mem. Inst. Oswaldo Cruz 101:15-20.

Sakai H., Barbosa Jr H.V., Silva E.M., Schlabitz F.O., Noronha R.P., Nonaka N., Franke C.R. \& Ueno H. 2001. Short report: seroprevalence of Taenia solium cysticercosis in pigs in Bahia State, Northeastern, Brazil. Am. J. Trop. Med. Hyg. 65:268-269.

São Paulo 2008. Census Survey of the Agricultural Farms at the State of São Paulo. Departament of Agriculture and Supply of the state of São Paulo, Technical Departament, Jaboticabal city, state of São Paulo, Brazil.

Sato M.O., Cavalcante T.V., Sako Y., Nakao M., Yamasaki H., Yatsuda A.P., Nakaya K. \& Ito A. 2006. A Short-report: evidence and potential for transmission of human and swine Taenia solium cysticercosis in Piracuruca Region, Paiuí, Brazil. Am. J. Trop. Med. Hyg, 75:933-935.

Sikasunge C.S., Phiri I.K., Phiri A.M., Dorny P., Siziya S. \& Willingham III A.L. 2007. Risk factors associated with porcine cysticercosis in selected districts of Eastern and Southern provinces of Zambia. Vet. Parasitol. 143:59-66.

Silva M.C., Cortez A.A., Aquino-Cortez A., Valent M. \& Toniolli R. 2007. Porcine cysticercosis, taeniasis and human neurocysticercosis in municipal district of Barbalha, Ceará, Arq. Bras. Med. Vet. Zootec. 59:371-375.

Silveira-Lacerda E.P., Machado E.R., Arantes S.C.F. \& Costa-Cruz J.M. 2002. Anti-Taenia solium metacestodes antibodies in serum from blood donors from four cities of Triângulo Mineiro Area, Minas Gerais, Brazil, 1995. Revta Instit. Med. Trop. São Paulo 44:229-231.

Thrusfield M.V. 2010. Veterinary Epidemiology. 3rd ed. Rocca, São Paulo. $556 \mathrm{p}$.

Towbin, H., Staehelin T. \& Gordon I. 1979. Electrophoretic transfer of proteins from polyacrylamide gels to nitrocellulose sheets: procedure and some applications. Proc Natl Acad Sci U S A. 76(9):4350-4354.

Weka R.P., Ikeh E. \& Kamani, J. 2013. Seroprevalence of antibodies (IgG) to Taenia solium among pig reares and associated risk factors in Jos metropolis, Nigeria. J. Infect. Dev. Ctries 7:67-72. 